\title{
Bezpečnostní politika proti diváckému násilí v České republice ve srovnání s evropskými frankofonními zeměmi
}

\section{Security policy against spectator violence in the Czech Republic compared with European French-speaking countries}

\author{
Vendula Divišová \\ Fakulta sociálních studií Masarykovy univerzity v Brně
}

\begin{abstract}
Abstrakt
Přispěvek se zabývá bezpečnostní politikou proti diváckému násilív České republice ve srovnání s vybranými zeměmi západní Evropy. Objektem srovnání budou přitom frankofonní země, jejichž politika $v$ této oblasti se v ČR př́liš nediskutuje, a to Francie, Belgie a Švýcarsko. Pozornost je věnována zejména opatřením zaměřeným na jednotlivce a jejich rizikové chování, spiše než na instituce relevantnív dané oblasti. Popis existujicích opatření ve vybraných zemích včetně kontextu jejich prijetí má vést k posouzení vhodnosti úpravy ČR a k reflexi, zda může být prínosné více se inspirovat v zahraničí mimo typicky vzorové země, jako jsou Anglie, Německo či Nizozemí.
\end{abstract}

\begin{abstract}
The paper deals with the security policy against spectator violence in the Czech Republic in comparison with selected Western European countries. For the purpose of comparison, French-speaking countries, whose security policy in the field is not much discussed, are chosen on purpose; these are France, Belgium and Switzerland. Attention is paid especially to measures targeted on individuals and their risk behavior rather than to relevant institutions in the field. The description of existing measures and the context of their adoption in the selected cases should lead to evaluation of the Czech security measures and to discussion whether it could be helpful to draw more inspiration in the foreign countries besides the countries typically serving as examples in the field, as England, Germany or Netherlands are.
\end{abstract}

Klíčová slova: Divácké násilí; fotbaloví chuligáni; ultras; bezpečnostní politika; Česká republika; Francie; Belgie; Švýcarsko.

Keywords: Spectator violence; football hooligans; ultras; security policy; Czech republic; France; Belgium; Switzerland.

\section{ÚVOD}

Článek se zabývá bezpečnostní politikou České republiky v oblasti diváckého násilí ve srovnání s evropskými frankofonními zeměmi. Region západní Evropy je z hlediska ČR obecně považován jako legislativně vyspělejší, a je tak častým zdrojem inspirace české bezpečnostní politiky. Text se záměrně vyhýbá zemím, které jsou nejčastěji uváděné jako vzor hodný následování v oblasti opatření proti diváckému násilí, jako jsou zejména Anglie, Nizozemsko a Německo.

Pozornost bude naopak zaměřena na frankofonní ${ }^{1}$ evropské země, a to Francii, Belgii a Švýcarsko. Z hlediska výzkumu je spojuje to, že o jejich bezpečnostní politice vůči diváckému násilí není dostupné takové množství materiálů v anglickém jazyce, což může mít nepochybně vliv

\footnotetext{
${ }^{1}$ Ve smyslu zemí, kde je francouzština alespoň jedním z úředních jazyků. $Z$ analýzy nicméně budou vyjmuty Monako a Lucembursko, a to $\mathrm{z}$ toho důvodu, že v obou zemích divácké násilí obecně není považováno za závažnou hrozbu.
} 
také na to, kolik pozornosti se jim v našem regionu dostává. Tyto země mají poměrně zajímavé a různorodé zkušenosti s násilím ve spojení se sportovními utkáními. Liší se tak i jimi přijatá bezpečnostní opatření. Jak bude $\mathrm{z}$ textu patrné, fenomén diváckého násilí je $\mathrm{v}$ Belgii již více než dekádu v útlumu, země se však s fotbalovými chuligány potýkala už poměrně brzy. Naopak ve Švýcarsku a Francii dosahuje tento fenomén obecně spíše nízké intenzity. K nárůstu případů diváckého násilí a jejich politizaci tak v obou zemích dochází teprve v poměrně nedávné době (přibližně kolem roku 2006), a legislativa v oblasti prochází poměrně dynamickým vývojem i v posledních několika letech.

Cílem textu je upozornit na různorodost fenoménu diváckého násilí i opatření proti jeho projevům a zároveň ohodnotit prístup ČR z trochu jiného pohledu a v jiné srovnávací perspektivě, než bývá obvyklé. To může napomoci poukázat na specifika české bezpečnostní politiky v oblasti diváckého násilí a zvážit, zda může být přínosné inspirovat se více také například v těchto evropských zemích nebo mnoha dalších.

Vzhledem k omezenému rozsahu práce, bude text spiše průřezového charakteru se zaměřením na současně existující arsenál bezpečnostních opatření, která ve vybraných zemích existují, kontext jejich přijetí a současné debaty. Primárním předmětem zájmu tak jsou konkrétní nejvýznamnější legislativní opatření cílící spíše na jednotlivce a jejich rizikové chování, než instituce a jejich kompetence v této oblasti.

Práce uživá termín divácké násilí z toho důvodu, že některé země se v této oblasti nepotýkají jen s fotbalovými chuligány, ale rovněž s násilnými projevy u jiných sportů. Ve Švýcarsku jsou například opatření cílena stejně tak na fotbalová, jako na hokejová utkání. Většina opatření a debat nicméně směřuje výhradně na fotbal.

\section{1 Česká republika}

V ČR dochází ke sporadickému výskytu projevů fotbalové chuligánství zhruba od poloviny 80. let. Určitou konsolidaci a organizovanost fotbalových chuligánů můžeme sledovat spíše až v druhé polovině 90 . let (Smolík 2010: 160). K politizaci fenoménu pak došlo hlavně pod vlivem pár závažnějších incidentů, které byly silně medializované (Smolík 2008: 126-127). Ve světle těchto incidentů došlo k úpravě stávající legislativy v roce 2006, ač ta př́liš nového nepřinesla (Ibid.: 133-134). Postihy za nevhodné chování spojené se sportovními utkáními každopádně zpř́isnila, když neslušné chování nebo narušení průběhu sportovního utkání dovolila trestat odnětím svobody až na dva roky, v případě příslušnosti pachatele $\mathrm{k}$ organizované skupině pak až na dobu tří let (MVČR 2008: 8).

Roku 2008 byla Ministerstvem vnitra přijata koncepce „Návrhy opatření k řešení problematiky diváckého násilí“ v kontextu vnímaného nárůstu intenzity fenoménu v ČR (dále jen „Koncepce“). Hlavní myšlenkou koncepce je jasné rozdělení práv a povinností jednotlivých aktérů zainteresovaných v rámci zajištování bezpečnosti v souvislosti se sportovními utkáními. Cílem je především to, aby primární zodpovědnost ležela na pořadatelích, zatímco Policie ČR má zaujímat subsidiární roli, v př́ípadě že pořadatelé nemohou situaci zvládnout sami (MVČR 2008). Tato potřeba se odrazila v novele zákona č. 115/2001, Sb. o podpoře sportu. Ten s účinností od začátku roku 2009 stanovuje povinnosti pořadatele spojené se sportovními zápasy a v př́ípadě jejich neplnění umožňuje uzavření sportovního podniku pro návštěvníky až na jeden rok, nebo povinnost uhradit náklady spojené se zásahem PČR (MVČR 2010).

Koncepce dále zvažuje přijetí trestu zákazu vstupu na stadiony. Konstatuje přitom, že už tehdy bylo v rámci podmíněného upuštění od trestání možné omezit vstup na sportovní akce na zkušební dobu až jeden rok. Česká legislativa umožňovala rovněž uvalení trestu zákazu činnosti na dobu až 10 let, ale ten - ač je vázaný na konkrétní vymezenou oblast napojenou na prrípadnou trestnou činnost - nebylo z jeho podstaty možné aplikovat př́mo na sportovní akce (MVČR 2008: 2-3)

Alternativní trest zákazu vstupu na sportovní, kulturní a jiné společenské akce byl nakonec přijat $\mathrm{v}$ roce 2010 jako soudní opatření v rámci trestního zákoníku. Tento trest je přitom možné uložit pouze za úmyslně spáchaný trestný čin na dobu až deset let. Zároveň se zákazem vstupu 
je možné uložit povinnost dostavit se v době zápasu, na který se zákaz vztahuje, na určený útvar PČR. Při této př́ležitosti může s fanouškem dále pracovat probační a mediační služba. Využít je možné rovněž zkráceného řízení, kdy jsou přestupky nebo trestné činy projednávány př́imo na stadionu nebo v jeho bezprostř̌ední blízkosti (MVČR 2010).

Tento trest zákazu vstupu však podle některých není využíván dostatečně, protože i z většího počtu zadržených se podaří dostat před soud jen malou část z nich. Vyslovena byla dokonce i možnost, že by tyto zákazy vstupu bylo možné do budoucna uložit jako doživotní (viz např. Koděra 2014). Slabinou tohoto opatření je již zmiňovaná skutečnost, že ho lze uložit jen za trestný čin, nikoliv za přestupek, a že se může vztahovat jen na konkrétní objekt, nikoliv na perimetr v jeho okolí (MVČR 2010).

V ČR se zpř́snění bezpečnostních opatření v souvislosti se sportovními utkáními diskutují periodicky, když dojde $\mathrm{k}$ násilnějším incidentům na fotbalových stadionech. Ta však většinou zůstávají v rétorické rovině. Typickou součástí těchto debat je porovnávání české legislativy s tou zahraniční, nejčastěji skloňovanými zeměmi jsou Anglie, Nizozemsko a Německo, případně ještě Polsko a v nedávné době také Slovensko (srovnej např. Koděra 2014, MVČR 2005: 19, MVČR 2008: 1,3, MVČR 2010: 23, Suchan 2010). Opakovaně se debatuje zejména zavedení adresného ticketingu, registrace fanoušků, případně zavedení databáze fanoušků problémových. Otevírá se rovněž otázka přijetí samostatného zákona zaměřeného na divácké násilí po vzoru zemí, jako je Anglie.

Adresný ticketing je v posledních letech velmi intenzivně a často debatován. Na některé rizikové zápasy se již využivá, zatím však nebyl přijat plošně jako povinný pro všechny prvoligové kluby. Ten by pak dle některých bylo vhodné podepřít využitím biometrických technologií nebo zavedením tzv. karty fanouška (srovnej např. Mádl 2014). Prozatím se však v českém fotbale nedostává finančních prostředků ani na kamerové systémy na stadionech. Bez nich jsou diskuse o biometrice bezpředmětné.

Otázka možného zavedení registrace fanoušků typicky naráží na argument, že by takové opatření „obtěžovalo“ slušné fanoušky. Jako možné řešení, které by bylo více zaměřené na problémový segment diváků, je tak prezentováno zřízení databáze problémových fanoušků (ČT24 2014a, MVČR 2014a, MVČR 2014b). I to zatím zůstává v rétorické rovině.

Specifický zákon zaměřený na divácké násilí dosud v ČR přijat nebyl s argumentem, že nástroje v rámci existujících skutkových podstat trestných činů jsou dostatečné, je však třeba jich řádně využívat (MVČR 2008, MVČR 2010: 4). Dalším argumentem pak bylo tvrzení, že sama skutečnost, že Anglie takovým zákonem disponuje, „není důvodem pro jeho kopírování a že obecně právní systém Anglie je cizí kontinentálnímu právu se svým důrazem na precedenty a nižší mírou kodifikace (MVČR 2008: 8). Specifické zákony zaměřené na zajištění bezpečnosti během sportovních utkání byly přitom již tehdy poměrně běžné i v západní kontinentální Evropě (viz níže).

Zhruba v posledním roce se začala výrazně artikulovat potřeba omezit na stadionech vedle výtržností a používání pyrotechniky také verbální násilí. Důraz je kladen zejména na využívání možnosti přerušení zápasu rozhodčím, nebo jeho úplné ukončení (srovnej např. ČT 2014b). To do značné míry koreluje s protesty fanoušků proti fotbalovým autoritám, jako je zejména FAČR.

Vedle represivního př́istupu se objevují i pokusy o větší využivání př́istupu socio-preventivního. Nicméně zatím se jedná spíše o jednotlivé lokálně zaměřené projekty a zastřešující celonárodní koncepce neexistuje. Vedle Ministerstva školství se v tomto ohledu angažuje zejména Ministerstvo vnitra, které tento přistup podpořilo již ve výše zmiňované koncepci z roku 2008 i ve „Zprávě o situaci v oblasti diváckého násilí, dopadu koncepce v praxi a návrzích dalších opatření z roku 2010“, a Policie ČR (srovnej např. Suchánek, Mareš 2013: 113-114). Celkově se tak u nás zatím jedná o okrajovou a nekoncepční součást bezpečnostní politiky v oblasti diváckého násilí. 


\section{Francie}

Ve Francii se násilí v souvislosti s fotbalovými utkáními začíná sporadicky objevovat od 70. let. Od poloviny 80 . let dochází s nárůstem ultras uskupení i k nárůstu fyzického násilí, z něhož část je doprovázena projevy pravicového extremismu. V současnosti lze divácké násilí ve Francii označit jako apolitické a postrádající projevy rasismu, snad s výjimkou pařižského Paris Saint-Germain/ PSG. Ultras uskupení byla v zemi tradičně mnohem početnější ve srovnání s fotbalovými chuligány², kteří byli koncentrováni převážně v okolí Pařiže, na severu a západu země. Podle některých autorů už však toto dělení pro Francii postrádá relevanci a v zemi působí jen fotbaloví ultras (Hourcade, Lestreline, Mignon 2010, SIRC 1996).

Do 90. let je tato problematika řešena v rámci existující legislativy. Obecně lze konstatovat, že ke zpř́ísnění legislativy v zemi dochází s výskytem násilných incidentů na fotbalových stadionech. Právě násilné střety fotbalových fanoušků s policií byly motivací pro zákon z roku 1993 (známý jako „Zákon Alliot-Marie“) zaměřující se specificky na bezpečnost v souvislosti se sportovními utkáními. Ten určuje trestní postihy za různé typy nevhodného chování na fotbalových stadionech a poprvé zavádí soudní zákaz vstupu na stadion na dobu až pět let včetně možnosti uložit zároveň povinnost hlásit se $\mathrm{v}$ době zápasů na místo určené příslušným úřadem. Ještě před Mistrovstvím světa v roce 1998, které Francie hostila, jsou opatření zpř́íněna, tak aby bylo možné zákaz aplikovat i v okolí stadionu a na veřejných prostranstvích, kde jsou pořádány přenosy zápasů (Loi Alliot-Marie 1993, Ministère des Sports 2012, Tsoukala 2013: 142).

$\mathrm{K}$ dalšímu zpřísnění represivních opatření dochází v roce 2006 po násilných střetech vyvolaných fanoušky PSG. ${ }^{3}$ Přijat je správní zákaz vstupu na stadion na dobu až 12 měsíců, v případě recidivy až na dva roky, společně s možností uložit povinnost hlásit se na policejní stanici. Je rovněž možné uložit zákaz vycestovat na zápas hraný mimo domácí stadion, a to jak pro jednotlivce, tak pro celou skupinu (Hourcade, Lestreline, Mignon 2010: 54, Légifrance 2013: 56). V oblasti správních opatření proti diváckému násilí bylo přijato ještě jedno poměrně unikátní opatření. Ministr vnitra může dekretem rozpustit uskupení fanoušků až na jeden rok po opakovaném užití násilí, ničení majetku nebo podněcování k nenávisti, anebo kvůli násilí s rasistickým či xenofobním kontextem (Légifrance 2013: 56-57, 195). ${ }^{4}$

$\mathrm{V}$ roce 2010 došlo $\mathrm{k}$ dalším násilným střetům mezi fanoušky PSG a Marseille, při kterých jeden muž zemřel (Le Figaro 2010). Tentýž rok byly ustanoveny speciální policejní síly, Oddíly rychlého zásahu (Séctions d'Intérvention Rapide). Ty mají funkci určitého přechodu mezi pořadateli a těžkooděnci. Během zápasu čekají v útrobách stadionu připraveni zasáhnout $\mathrm{v}$ prrípadě, že dojde $\mathrm{k}$ jakémukoliv incidentu. Jsou přitom vybaveni kamerami a mají možnost vyslýchat fanoušky za incident zodpovědné a př́padně jim rovnou uložit zákaz vstupu na stadion. Nasazení těchto sil probíhají za pomoci záznamů z kamerového systému na stadionu (Ministère de l’Intérieur 2010).

V současnosti probíhají debaty o dalším posílení nástrojů v oblasti diváckého násilí v souvislosti s dalšími násilnými incidenty a s výhledem na hostování EURA 2016. Předmětem diskusí se stala především možnost uložit zákaz vycestovat pro fanoušky „venkovního“ týmu jako celek, nebo podrobení se v rámci takových výjezdů na zápasy venku striktní kontrole. Ta jsou zatím zvažována jako krajní možnost. Předmětem debat je rovněž další prodloužení zákazu vstupu na stadion

\footnotetext{
${ }^{2}$ Zatímco fotbaloví chuligáni přejímají anglický model a jejich primárním motivem je aktivní vyhledávání násilí původně zejména s chuligány soupeřících týmů, cílem ultras je tvořit atmosféru na stadionu během zápasu pomocí popěvků, chorea (tzv. tifos), vlajek, bubnů atp. Primárním cílem je tak aktivní fanouškovství, spíše než vyhledávání násilných střetů. $\mathrm{V}$ praxi se však i př́slušníci ultras uchylují k použití násilí, jehož intenzita je však různorodá (srovnej napr. Spaaij 2006: 22-23, Spaaij, Viñas 2005: 80).

${ }^{3} \mathrm{~V}$ listopadu téhož roku pak ještě v souvislosti se zápasem mezi PSG a Hapoël Tel-Aviv dochází k úmrtí jednoho z fanoušků po zásahu policisty, poté co fanoušci pařížského klubu napadli hostující (např. Le Monde 2006).

${ }^{4}$ Tato opatření ve správní oblasti byla prijiata v rámci v podstatě protiteroristického zákona (Tsoukala 2013: 140).
} 
(viz např. Le Point 2014). V dubnu 2015 pak bylo přijato nařízení ministra vnitra, které povoluje nakládání s osobními údaji za účelem předejít narušení veřejného pořádku, ohrožení bezpečnosti osob a majetku u příležitosti sportovních utkání, ale i shromáždění s nimi spojená, odehrávající se v pařížských departementech anebo ve spojitosti s klubem Paris Saint-Germain (Légifrance 2015).

\section{Belgie}

V Belgii obecně není divácké násilí považováno za velkou hrozbu, v první dekádě 21 . století se mluví o úpadku tohoto fenoménu v zemi, což je přičítáno nejen přijatým bezpečnostním opatřením v oblasti ${ }^{5}$, ale také absenci generační obměny v řadách fotbalových chuligánů, přičemž nastupující generace rizikových fanoušků tolik násilné střety nevyhledává ${ }^{6}$. Obecně tedy dochází k poklesu incidentů zahrnujících fyzické násilí, jež se do určité míry přesouvají mimo stadiony, do jiných sportů, případně do zcela jiných kontextů, jako jsou například diskotéky (La Libre 2013, SPF Intérieur 2006). Celkově lze hovořit o tzv. situační prevenci, která sice dokázala zamezit vzniku násilných incidentů na fotbalových stadionech, ale nedokázala zcela zabránit jejich přesunu mimo stadiony. Zástupci státní správy sami upozorñují, že v takovém případě nemusí být pokles násilí na stadionech považován za úspěch (SPF Intérieur 2006: 7-8, 79). Stejný trend je sledován i ke konci dekády s tím, že s ústupem fyzické agrese vzrůstá počet menších a méně závažných incidentů, jako je nepovolené používání pyrotechniky, nebo verbální násilí.

Speciální zákon věnující se bezpečnosti v souvislosti s fotbalovými utkáními (tzv. loi football) fotbalový zákon) byl přijat v roce 1998 a novelizován v roce 2003 a 2007. Zákon velmi komplexně upravuje problematiku bezpečnosti v kontextu fotbalových zápasů. Specifikuje zejména roli a povinnosti pořadatele jako primárně zodpovědného aktéra za bezpečnost na stadionech (zároveň povinnosti stewardů), přičemž pořadatelé mohou být $\mathrm{v}$ př́ípadě podcenění bezpečnostních opatření potrestáni pokutou ve výši 500 až 250000 eur (Ministère de l'Intérieur. 2007).

Většina obsahu zákona je nicméně věnována rizikovému chování diváků, přičemž přesně stanovuje výši trestu, jeho uložení a provádění. Pachatele identifikovaných skutků narušujících veřejný pořádek je možné podle zákona postihovat pokutou v rozmezí 250 až 5000 eur, správním zákazem vstupu na dobu od tří měsíců do pěti let $\mathrm{v}$ závislosti na typu provinění dle zákona a s ohledem na možnou recidivu? ${ }^{7}$ Tento zákaz vstupu je možné zároveň aplikovat i na stanovený perimetr kolem stadionu (nejvýše do pěti kilometrů) a povinností hlásit se v danou dobu na policejní stanici. Zároveň u zákazů vstupu uloženého na dva roky a více, je možné nařídit zákaz vycestovat do země, kde se odehrává zápas týmů, na něž se zákaz vztahuje. Ten je opět možné doplnit povinností hlásit se na policejní stanici. Stejná opatření lze uložit i soudně ve formě soudního zákazu vstupu. V tomto prrípadě je možné uložit trest na tři měsíce až 10 let. Od roku 2007 pak může král stanovit další dodatečná opatření, která však podléhají schválení zákonem do 12 měsíců od jejich vstupu v platnost (Loi de Football 2007: 13-19).

Belgický fotbalový zákon dobře ilustruje význam kontextu, ve kterém je bezpečnostní politika vytvářena vzhledem $\mathrm{k}$ tomu, že je $\mathrm{v}$ něm kladen bezprecedentní důraz (ve srovnání s ostatními zeměmi) na zajištění bezproblémové evakuace nepochybně pod vlivem Heyselovy tragédie z června 1985. V tomto smyslu je klíčová zejména role stewardů (Ibid.: 10).

Vedle tohoto zákona postaveného na dominantně represivních opatřeních a situační prevenci, přijalo ministerstvo vnitra rovněž dokument zaměřený explicitně na sociální prevenci diváckého násilí (na základě doporučení Rady Evropy), a to roku 2006 pod názvem „Nejlepší praktiky:

\footnotetext{
${ }^{5}$ Mezi tato opatření lze řadit nejen přijetí speciální legislativy, ale také oddělení fanoušků soupeřících týmů, zlepšení postupů policie, využívání tzv. spotterů, fancoaching, ale i zlepšení infrastruktury stadionů (SPF Intérieur 2006: 89).

${ }^{6}$ Fotbaloví chuligáni v Belgii jsou tak stejní jako před 15 lety (La Libre 2013). V Belgii existují také hnutí ultras, tento fenomén se však vyvijí víceméně jen ve frankofonní části Belgie, zatímco ve Vlámsku typicky převažoval model anglický (SPF Intérieur 2006: 17-20).

${ }^{7}$ Je však možné přihlédnout $\mathrm{k}$ polehčujícím okolnostem.
} 
„Prevence násilí spojeného s fotbalem““ (Cellule football 2006). Ten se zakládá zejména na tzv.fancoachingu, jehož je Belgie průkopníkem. Cílem je, aby se činnost policejních sil nezakládala jen na silovém, represivním přístupu, ale i na přijetí fanoušků, dialogu a preventivních a proaktivních krocích (Ibid.: 7). Přičemž právě státní správa je garantem tohoto přístupu. V oblasti prevence zastávají důležitou roli v prevenci diváckého násilí obce v čele se starostou, protože samy rozhodují o konání či nekonání utkání v závislosti na zajištění bezpečnosti (Comeron 2003, Groupe cdH nedat.).

\section{4 Švýcarsko}

Ve Švýcarsku je identifikováno cca 1 500-2 000 fanoušků jako náchylných k použití násilí v souvislosti se sportovními utkáními. Fotbalových chuligánů, kteří násilné střety prrímo vyhledávají, bylo v zemi identifikováno v rozmezí 200-300 osob. Z nich by přibližně $10-15 \%$ mohlo být napojeno na krajní pravici, přičemž vzájemné propojení těchto dvou subkultur je považováno stále za marginální fenomén (Conseil Fédéral 2008).

Ještě v roce 2003 konstatovala Rada Evropy, že ve Švýcarsku dochází v souvislosti se sportovními utkáními k násilným střetům jen málokdy, nicméně už od roku 2006 začalo být násilí spojené se sportovními utkáními vnímáno jako palčivý problém, jenž si žádá přijetí zvláštních opatření a cestu zvýšené represe (Ibid. 2008). Hlavním impulsem pro tento obrat se staly zejména výtržnosti spojené se zápasem fotbalové ligy mezi Bazilejí a Curychem, svou roli však nepochybně sehrála také skutečnost, že se Švýcarsko chystalo na hostování EURA 2008 a Mistrovství světa v hokeji o rok později (swissinfo.ch 2008).

Ještě téhož roku přijal parlament skrze novelu federálního zákona $\mathrm{v}$ oblasti vnitřní bezpečnosti soubor nových nástrojů zahrnující zejména: vytvoření národní databáze chuligánů (tzv. databáze HOOGAN), zákaz vstupu do perimetru zahrnujícího stadion na dobu až jeden rok, který lze doprovodit povinností hlásit se v určenou dobu na policejní stanici, omezení vycestovat na venkovní zápasy pro „známé výtržníky“, ale i preventivní zadržení rizikového fanouška na dobu až 24 hodin. Tato opatření byla zahrnuta do federálního zákona upravujícího zajištování vnitřní bezpečnosti země. Platnost některých ustanovení však musela být omezena (do konce roku 2009 alespoň pro potřeby obou pořádaných šampionátů), protože dle ústavy je konfederace zodpovědná pouze za trestní právo. To se ale netýká preventivních opatření, za která jsou primárně zodpovědné samy kantony. Kantony spolu proto uzavřely tzv. konkordát (v listopadu roku 2007), který opatření k 1. lednu 2010 opět nastolil, a to již natrvalo. Jednotlivé kantony následně konkordát ratifikovaly (CCDJP 2012: 4-5; humanrights.ch 2014).

Už od začátku roku 2008 došlo skutečně k poklesu výskytu násilných incidentů a také EURO 2008 proběhlo z hlediska bezpečnosti bez větších problémů. Nicméně už po skončení turnaje je konstatována výraznější tendence uchylovat se v souvislosti s fotbalovými i hokejovými zápasy k násilí, a to jak mezi chuligány, tak v řadách ultras. Zároveň narůstá ochota „nerizikových“ fanoušků přidávat se ze solidarity $\mathrm{k}$ agresím směřujícím například proti policii a roste rovněž počet př́ipadů použití pyrotechniky na stadionech (za použití i jako projektilů). Vzestupný trend se týká i počtu skupin, které se $\mathrm{k}$ násilí uchylují. S přijatými bezpečnostními opatřeními navíc dochází k přesunu násilí mimo stadiony a znásobení se výskytu násilných incidentů na lokální úrovni, což dále ztěžuje tento fenomén předvídat a kontrolovat (CCDJP 2012: 2, 5, CoE 2011).

Na začátku roku 2012 byla jednomyslně přijata revize výše zmíněného konkordátu mezi kantony, která dále posílila nástroje ke kontrole a potlačování diváckého násilí. Stalo se tak právě $\mathrm{v}$ atmosféře násilných událostí na fotbalových zápasech a zároveň s přihlédnutím na opatření v zemích, jako je Anglie, Nizozemsko, Belgie či Německo (CCDJP 2012: 5-8). Policii bylo nově umožněno provádět bezpečnostní kontroly fanouškủ při vstupu na stadion, a to i pod oděvy a v případě podezření na intimních místech, a dokonce $\mathrm{i} v$ tělních dutinách (v tomto případě prováděno lékařským personálem a v soukromí). Již existující opatření byla dále zpř́sněna, zákaz vstupu do perimetru kolem stadionu bylo nově možné uložit na jeden až tři roky a úřady získaly možnost používat databanku HOOGAN. Zcela novým opatřením pak bylo zavedení pravomoci 
pro kantonem stanovený úřad schvalovat odehrání zápasu klubů z nejvyšších lig v návaznosti na splnění jimi stanovených podmínek. Těmi mohou být např́klad technická a architektonická opatření, počet pořadatelů, ale i pravidla prodeje vstupenek s tím, že na konkrétní zápas tak může být podmínkou povolit vstup diváků jen po předložení občanského průkazu (Ibid.).

Konkordát čelil poměrně velké kritice kvůli svému údajnému nesouladu se základními lidskými právy. Po přezkoumání soudu tak byl znovu pozměněn v roce 2014 za konstatování, že většina opatření je v souladu s těmito právy a pouze dvě ustanovení je třeba pozměnit z pohledu jejich proporcionality. Zákaz vstupu do perimetru tak nově musí být možné uložit i na dobu kratší než jeden rok. Ustanovení z roku 2012, že v případě porušení povinnosti dostavit se v souvislosti se zákazem vstupu na určené místo bez opodstatněného důvodu, se doba trvání trestu automaticky zdvojnásobuje, bylo zrušeno úplně (Tribunal Fédéral 2014: 1-2).

\section{ZÁVĚR A DISKUSE}

Dunning, Murphy a Waddington tvrdí, že rozdíly ve fenoménu fotbalového chuligánství „pravděpodobně vyvstanou ve vztahu ke konkrétním trajektoriím ekonomického, politického a kulturního vývoje v různých zemích a regionech“ (Dunning et al. 2002, cit. dle Spaaij, Viñas 2005: 80). Je evidentní, že to samé lze do určité míry konstatovat v případě bezpečnostní politiky v oblasti diváckého násilí.

Ve Švýcarsku je v kontrastu s ostatními zeměmi divácké násilí považováno za problém, který si žádá přijetí zvláštních opatření, až v letech, kdy jiné evropské země už hlásí spíše útlum fenoménu. V zemi tak byla legislativa zaměřující se specificky na bezpečnost při sportovních utkáních prijiata až poměrně pozdě (od roku 2007) s výhledem na hostování dvou mezinárodních šampionátů. Přijatá opatření jsou přitom velmi přísná a represivní. Některá ustanovení musela být dokonce z hlediska jejich proporcionality po posouzení federálním soudem upravena.

Belgie si s sebou ve své bezpečnostní politice nese trauma Heyselské tragédie, která se odehrála na jednom z belgických stadionů, ač bez účasti belgického týmu. Žádná jiná země ze zde srovnávaných neklade $\mathrm{v}$ rámci své specifické fotbalové, resp. sportovní legislativy takový důraz na bezproblémové zajištění evakuace na stadionech. Belgie se především sama potýkala s generací fotbalových chuligánů klasického střihu. Ke konci 90. let tak byl přijat specifický fotbalový zákon a později několikrát novelizován. Belgie př́ísnou a poměrně komplexní legislativu doplňuje výrazně také socio-preventivními aktivitami na lokální úrovni a je jedním z průkopníku fancoachingu. V současnosti divácké násilí není v zemi považováno za společenský problém, který by se nedařilo zvládat existujícími prostředky. Výraznou roli na tom však má zřejmě generační obměna v subkultuře fotbalových chuligánů. Je tak otázkou, do jaké míry a s jakou garancí úspěchu lze belgický fancoaching přenést do jiných kontextů.

Ve Francii je v západoevropském srovnání intenzita diváckého násilí spíše nízká. Mnohé z deklarovaných incidentů se tak týkají spíše nepovoleného užití pyrotechniky. Násilné incidenty na zápasech (převážně za účasti fanoušků pařižského PSG) - některé bohužel končící i tragicky úmrtím fanouška - nicméně opakovaně vyvolaly nekompromisní odezvu státního aparátu. V zemi je tak bezpečnostní politika $\mathrm{v}$ této oblasti velmi represivní $\mathrm{v}$ duchu nulové tolerance, přičemž další zpřísnění jsou předmětem debat, a to nepochybně pod vlivem nadcházejícího hostování Mistrovství Evropy ve fotbale v roce 2016. Mnohá z opatření byla navíc přijímána i v kontextu jiných bezpečnostních hrozeb (sociální nepokoje, terorismus).

Také v České republice dochází k politizaci diváckého násilí a přijetí či zpř́ísnění nástrojů k jeho zvládání po výskytu násilných incidentů. Mnohé debaty však neopouštějí rétorickou rovinu, a v ČR tak existuje omezenější množství nástrojủ, jak se s fenoménem vypořádat. Ty jsou většinou vyhodnoceny jako dostatečné a důraz je kladen spíše na přenesení hlavního dílu odpovědnosti na pořadatele sportovních podniků a větší využivání již existujících nástrojů. Prozatím také bezpečnostní opatření (v oblasti represe) zůstávají v rovině trestního práva a přijetí specifické legislativy ve formě samostatného zákona upravujícího divácké násilí není považováno za nezbytné. 
Celkově lze konstatovat, že přijatá opatření nutně nekorelují s vážností fenoménu v jednotlivých zemích, ale jsou často výsledkem tvrdé odezvy na incidenty, u kterých došlo k mimořádným výtržnostem, nebo které skončily tragicky. Nadcházející hostování mezinárodního šampionátu pak často legislativní změny nepochybně urychluje. I přes výrazné odlišnosti ve fenoménu diváckého násilí v jednotlivých zemích, které by tak logicky měly vést $\mathrm{k}$ odlišným opatřením uzpůsobeným místním podmínkám a kontextu, existuje neustále potřeba vyhodnocovat vlastní bezpečnostní politiku prizmatem zkušeností v okolních evropských zemích. Tsoukala (1996) hovoří o určité „homogenizaci“ policejních strategií v Evropě v oblasti zvládání fotbalových chuligánů. Tvrdí, že navzdory odlišným realitám jsou všechna opatření v konečném součtu zaměřena na oddělení (segregaci) fanoušků a kontrolu bojujíce tak proti symptomům, místo aby řešila příčiny fenoménu. Od doby vydání jejího článku už některé země přijaly i opatření v oblasti socio-preventivní. Ze zde zkoumaných zemí však tento přístup hraje důležitější roli jen v Belgii, a je tak zatím obecně spiše výjimkou, než systematickým opatřením aplikovaným shora. Závěry Tsoukaly tak prozatím svou relevanci neztrácí.

V kontextu zde vybraných zemí vyčnívá česká bezpečnostní politika ve více ohledech (viz přehledová tabulka níže). V první řadě je to zákaz vstupu na stadion, který lze nařídit pouze soudně a to až na 10 let (ač reálně se ukládané zákazy pohybují výrazně níže). Ve srovnání s výše uvedenými zeměmi je vrchní hranice deseti let bezkonkurenčně nejvyšší (s výjimkou Belgie, kde je vrchní hranice soudního zákazu totožná), když vezmeme v potaz, že správní zákaz česká legislativa uložit nedovoluje. Vysokou hranici trestu lze přičítat debatám obsaženým i v samotné koncepci z roku 2008, že případné zavedení alternativního trestu zákazu vstupu by mohlo překračovat hranici deseti let vytyčenou pro trest zákazu činnosti (MVČR 2008: 3), nebo deklarované inspirace u Anglie, kde je vrchní hranice opatření totožná. Kritizuje se přitom, že těchto zákazů není využíváno dostatečně, což je logické, když jejich uložení vyžaduje prokázání úmyslného spáchání trestného činu. Ostatní zde zkoumané země dovolují uvalení zákazu vstupu i v rovině správního procesu.

Vyčnívá rovněž skutečnost, že česká legislativa nedovoluje uložit zákaz vycestovat na zápasy týmu hrané v zahraničí, který je ve zkoumaných zemích už standardní součástí arzenálu bezpečnostních opatření založených na omezení pohybu rizikových fanoušků. Deklarovaná slabina, že zákaz se v ČR vztahuje pouze na konkrétní objekt (stadion), také většinu zkoumaných případů nesužuje díky možnosti opatření aplikovat i na stanovený perimetr v okolí stadionu. V př́padě Švýcarska to pak není možností, ale zákaz vstupu se na perimetr v okolí stadionu vztahuje automaticky.

Na rozdíl od ostatních zemí je pak v ČR patrné, že mnohé návrhy opatření nepřekračují rétorickou rovinu. Mnohé diskuse končí u konstatování, že je tř̌eba, aby za zajištění bezpečnosti na sportovních utkáních byli mnohem více zodpovědní pořadatelé, kteří by měli čelit sankcím v př́ipadě podcenění této povinnosti. Mnohdy je argumentováno tím, že legislativa je dostatečná, ale nevyužívá se dostatečně. Ve srovnání zde tak existuje spíše menší politická vůle legislativu zpř́íňovat. U ostatních zkoumaných zemí však nelze opomenout, jakou roli sehrály sporadické násilné události někdy i s tragickými důsledky a vyhlídka hostování mezinárodního šampionátu.

Je zřejmé, že zahraniční zkušenosti mimo vzorové země v oblasti bezpečnostní politiky proti diváckému násilí, jako je Anglie, Nizozemsko nebo Německo, by mohly být v ČR užitečné v debatách o vhodnosti či nedostatečnosti současné právní úpravy a obecně nastavení bezpečnostní politiky proti diváckému násilí. Je však zásadní sledovat vždy kontext, ve kterém bylo určité bezpečnostní opatření přijato a uvědomovat si, že existující nástroje v jednotlivých zemích mnohdy nejsou v souladu s objektivní mírou závažnosti fenoménu. 
Tabulka vybraných opatření v oblasti bezpečnostní politiky proti diváckému násilí (zdroj: vlastní)

\begin{tabular}{|c|c|c|c|c|}
\hline & Česká republika & Francie & Belgie & Švýcarsko \\
\hline $\begin{array}{l}\text { Speciální zákon } \\
\text { upravující } \\
\text { divácké násilí }\end{array}$ & ne (trestní zákoník) & $\begin{array}{l}\text { ano; další opatření } \\
\text { v rámci trestního nebo } \\
\text { sportovního zákoníku } \\
\text { (ve druhém případě } \\
\text { obecně přísnější } \\
\text { tresty) }\end{array}$ & $\begin{array}{l}\text { ano } \\
\text { (specificky pro fotbal) }\end{array}$ & $\begin{array}{l}\text { ve formě federálního } \\
\text { zákona kvůli } \\
\text { ústavnosti neexistuje, } \\
\text { ale existence } \\
\text { konkordátu mezi } \\
\text { kantony }\end{array}$ \\
\hline $\begin{array}{l}\text { Zákaz vstupu } \\
\text { na stadion / } \\
\text { do perimetru } \\
\text { kolem stadionu }\end{array}$ & $\begin{array}{l}\text { soudní zákaz vstupu } \\
\text { až na } 10 \text { let }\end{array}$ & $\begin{array}{l}\text { správní zákaz vstupu } \\
\text { až na } 1 \text { rok (v př́padě } \\
\text { recidivy až } 2 \text { roky); } \\
\text { soudní zákaz až } \\
\text { na } 5 \text { let; } \\
\text { možný dále zákaz } \\
\text { vstupu do perimetru }\end{array}$ & $\begin{array}{l}\text { správní zákaz } \\
\text { od } 3 \text { měsíců do } 5 \text { let; } \\
\text { soudní zákaz } \\
\text { od } 3 \text { měsíců do } 10 \text { let; } \\
\text { možné uvalit také } \\
\text { zákaz narušení } \\
\text { perimetru }\end{array}$ & $\begin{array}{l}\text { správní zákaz } \\
\text { vstupu do perimetru } \\
\text { zahrnujícího stadion } \\
\text { až na } 3 \text { roky }\end{array}$ \\
\hline $\begin{array}{l}\text { Povinnost hlásit se } \\
\text { na policejní stanici } \\
\text { v době zápasu }\end{array}$ & $\begin{array}{l}\text { ano; možná další } \\
\text { výchovná opatření } \\
\text { ze strany probační } \\
\text { a mediační služby }\end{array}$ & ano & ano & ano \\
\hline $\begin{array}{l}\text { Zákaz vycestovat } \\
\text { na zápas do zahraničí }\end{array}$ & ne & $\begin{array}{l}\text { ano; možné uložit } \\
\text { jednotlivci i skupině } \\
\text { v př́ipadě, kdy existuje } \\
\text { podezření, že by tito } \\
\text { mohli vážně ohrozit } \\
\text { veřejný pořádek }\end{array}$ & $\begin{array}{l}\text { ano; možný pro osoby } \\
\text { se zákazem vstupu } \\
\text { od } 2 \text { let }\end{array}$ & ano \\
\hline $\begin{array}{l}\text { Preventivní zadržení } \\
\text { rizikového fanouška }\end{array}$ & $\begin{array}{l}\text { ne; je ale možné využít } \\
\text { institutu zajištění } \\
\text { na dobu max. } 24 \\
\text { hodin (cílem primárně } \\
\text { zabránění páchání } \\
\text { dalšího protiprávního } \\
\text { jednání) }\end{array}$ & ne & ne & $\begin{array}{l}\text { ano (maximálně } \\
\text { na } 24 \text { hodin) }\end{array}$ \\
\hline $\begin{array}{l}\text { Rozpuštění uskupení } \\
\text { radikálních fanoušků } \\
\text { (ne jako kompetence } \\
\text { soudní moci) }\end{array}$ & ne & $\begin{array}{l}\text { ano (rozhoduje } \\
\text { Ministerstvo vnitra) }\end{array}$ & ne & ne \\
\hline $\begin{array}{l}\text { Národní databáze } \\
\text { problémových fanoušků }\end{array}$ & ne & $\begin{array}{l}\text { ne; ale nařízením } \\
\text { ministra vnitra } \\
\text { z dubna } 2015 \\
\text { umožněno } \\
\text { zpracovávání osobních } \\
\text { dat fanouškủ v Paří̌i } \\
\text { a v souvislosti } \\
\text { s klubem Paris } \\
\text { Saint-Germain }\end{array}$ & $\begin{array}{l}\text { centrální soubor } \\
\text { fotografií osob, které } \\
\text { mají zákaz vstupu } \\
\text { za účelem kontrolovat } \\
\text { dodržování tohoto } \\
\text { trestu }\end{array}$ & $\begin{array}{l}\text { ano (tzv. HOOGAN } \\
\text { databáze) }\end{array}$ \\
\hline $\begin{array}{l}\text { Prodej alkoholických } \\
\text { nápojů na stadionu }\end{array}$ & $\begin{array}{l}\text { zákaz s výjimkou } \\
10^{\circ} \text { piva }\end{array}$ & $\begin{array}{l}\text { zakázán (s výjimkou } \\
\text { lóží pro VIP hosty) }\end{array}$ & $\begin{array}{l}\text { pouze nízkoprocentní } \\
\text { pivo }\end{array}$ & $\begin{array}{l}\text { může podléhat } \\
\text { schválení př́islušným } \\
\text { úřadem v závislosti } \\
\text { na rizikovosti zápasu }\end{array}$ \\
\hline $\begin{array}{l}\text { Bezpečnostní } \\
\text { prohlídky před vstupem } \\
\text { na stadion }\end{array}$ & pouze přes oděv & pouze přes oděv & pouze přes oděv & $\begin{array}{l}\text { přes oděv, } \\
\text { i na intimních částech } \\
\text { těla, při podezření } \\
\text { i v tělních dutinách } \\
\text { (provádí lékařský } \\
\text { personál) }\end{array}$ \\
\hline
\end{tabular}




\section{Literatura}

CCDJP: Conférence des directrices et directeurs des départements cantonaux de justice et police. (2012). Concordat instituant des mesures contre la violence lors de manifestations sportives du 15 novembre 2007; modification du 2 février 2012, on-line text (http://www.kkjpd.ch/?action=get_file\&resource_id=2eb).

Cellule football et la Direction Sécurité locale intégrale. (2006). Meilleures pratiques: 'Prévention de la violence liée au football', on-line text (https://besafe.ibz.be/Publications/Pr\%C3\%A9vention\%20de\%20la\%20violence\%20li\%C3\%A9e\%20 au\%20football.pdf).

Comeron, M. (2003). Le role des autorités locales dans la prévention de la violence dans le sport en Europe, on-line text (http:// orbi.ulg.ac.be/bitstream/2268/136989/1/rapport_CPLREfoot_Lisbonne_2003.pdf).

Conseil fédéral sur le postulat de la Commission des affaires juridiques du Conseil des Etats. (2008). Violence lors de manifestations sportives. Mesures de prévention, on-line text (http://www.baspo.admin.ch/internet/baspo/fr/home/themen/ foerderung/spitzensport/0/gewaltbekaempfung.parsys.52144.downloadList.56658.DownloadFile.tmp/gewaltberichtfr. pdf).

CoE: Council of Europe. (2011). Country Profile. Switzerland, on-line text (http://www.coe.int/t/dg4/sport/Source/T-RV/ Country_profiles/Switzerland_EN.pdf).

ČT24: Česká televize. (2014a). „Na fotbal zatím pořád bez občanek. Ale s přísnějšími pořadateli“, 2-4-2014 (http://www. ceskatelevize.cz/sport/fotbal/synot-liga/268362-na-fotbal-zatim-porad-bez-obcanek-ale-s-prisnejsimi-poradateli/).

ČT24: Česká televize. (2014b).„Disciplinárka nenechá nadávky fanoušků bez odezvy“, 2-4-2014 (http://www.ceskatelevize. cz/sport/fotbal/271409-disciplinarka-nenecha-nadavky-fanousku-bez-odezvy/).

Groupe $\mathrm{cdH}$. (nedat.) Mesures pour lutter contre la violence lors des matches de football, on-line text (http://www.pcf-cdh.be/ questiondetails.php?id=546).

Hourcade, N., Lestreline, L. \& Mignon, P. (2010). Livre vert du supportérisme, on-line text (http://developpement-durable. sports.gouv.fr/m/download-ressource.php?file=830365LivreVertSupporters_17x24_Int_web.pdf).

humanrights.ch. (2014). Lutte contre le hooliganisme et droits fondamentaux, on-line text (http://www.humanrights.ch/fr/ droits-humains-suisse/interieure/protection/securite/lutte-contre-hooliganisme-droits-fondamentaux).

Koděra, P. (2014).„,Soudy nevyužívají naplno zákazy vstupu na stadion pro fotbalové chuligány“, Ihned.cz, 1-4-2014 (http:// domaci.ihned.cz/c1-61950160-soudy-nevyuzivaji-naplno-zakazy-vstupu-na-stadion-pro-fotbalove-chuligany).

La Libre.be. (2013). „Moins de hooligans dans les stades en Belgique“, 4-11-2013, on-line text (http://www.lalibre.be/sports/ football/moins-de-hooligans-dans-les-stades-en-belgique-52772d3e357046af56a07299).

Le Figaro. (2010). „Décès d'un supporteur agressé en marge d'un match PSG-OM“, 18-3-2010, on-line text (http://www. lefigaro.fr/sport/2010/03/18/02001-20100318ARTFIG00417-le-supporter-du-psg-agresse-est-mort-.php).

Le Monde. (2006).„Un supporteur du PSG tué par balle par un policier“, 24-11-2006, on-line text (http://www.lemonde.fr/ societe/article/2006/11/24/un-supporteur-du-psg-tue-par-balle-par-un-policier_838103_3224.html).

Légifrance. (2013). Code du Sport, on-line text (http://www.legifrance.gouv.fr/affichCode.do?cidTexte=LEGITEXT 000006071318).

Légifrance. (2015). Arrêté du 15 avril 2015 portant autorisation d'un traitement automatisé de données à caractère personnel dénommé « fichier STADE », on-line text (http://www.legifrance.gouv.fr/affichTexte.do;jsessionid=08CAAB8CA83A504E 64C15214A3FC101B.tpdila24v_1?cidTexte=JORFTEXT000030513627\&dateTexte=\&oldAction=rechJO\&categorieLien= id\&idJO=JORFCONT00003051313).

Le Point. (2014).,Violences dans les stades: Valls et le foot pro évoquent des mesures fortes“, 14-1-2014 (http://www.lepoint. $\mathrm{fr} /$ societe/violences-dans-les-stades-valls-et-le-foot-pro-evoquent-des-mesures-fortes-14-01-2014-1780247_23.php).

Loi Alliot-Marie: Loi n 93-1282 du 6 décembre 1993 relative à la sécurité des manifestations. (1993). Journal Officiel de la République Francaise, 7-12-1993, on-line text (http://bdoc.ofdt.fr/pmb/opac_css/doc_num.php?explnum_id=4561).

Mádl, L. (2014). „Liga jen na občanku či kartu fanouška. A usmějte se do kamer", Aktuálně.cz, 16-9-2014 (http://sport.aktualne.cz/liga-jen-na-obcanku-ci-kartu-fanouska-a-usmejte-se-do-kamer/r 8bc7da7e3d0d11 e4975f0025900fea04/).

Ministère de l'Interieur. (2007). Loi du 21 décembre 1998 relative à la sécurité lors des matches de football, modifiée par les lois des 10 mars 2003, 27 décembre 2004 et 25 avril 2007, on-line text (https://besafe.ibz.be/Publications/La\%20loi\%20 football\%202007.pdf).

Ministère de l'Interieur. (2010). Les sections d'intervention rapide font leur entrée dans les stades, on-line text (http://www. interieur.gouv.fr/Archives/Archives-des-actualites/2010/SIR-dans-les-stades).

Ministère des Sports, de la Jeunesse, de l'Education populaire et de la Vie associative. (2013). Guide juridique sur la prévention et la lutte contre les incivilités, les violences et les discriminations dans le sport, online-text (http://sports.gouv.fr/ IMG/pdf/guidejuridique.pdf).

MVČR: Ministerstvo vnitra ČR. Odbor bezpečnostní politiky. (2005). Informace o problematice extremismu na území České republiky $v$ roce 2003, on-line text (www.mvcr.cz/soubor/zprava-o-problematice-extremismu-2003.aspx).

MVČR: Ministerstvo vnitra ČR. Odbor bezpečnostní politiky. (2008). Návrhy opatření k řešení problematiky diváckého násilí, on-line text (http://www.mvcr.cz/soubor/2008-11-priloha-mala-pdf.aspx).

MVČR: Ministerstvo vnitra ČR. Odbor bezpečnostní politiky. (2010). Zpráva o situaci v oblasti diváckého násilí, dopadu koncepce v praxi a návrzích dalších opatření, on-line text (http://www.mvcr.cz/soubor/zprava-o-situaci-v-oblastidivackeho-nasili-pdf.aspx).

MVČR: Ministerstvo vnitra České republiky. (2014a). Násilí na fotbalových stadionech bude rešit společná pracovní skupina, on-line text (http://www.mvcr.cz/clanek/nasili-na-fotbalovych-stadionech-bude-resit-spolecna-pracovni-skupina.aspx). 
MVČR: Ministerstvo vnitra České republiky. (2014b). Milan Chovanec se sejde s majiteli klubů. Trvá na tom, aby brali bezpečnost na stadionech vážně, on-line text (http://www.mvcr.cz/clanek/milan-chovanec-se-sejde-s-majiteli-klubu-trva-na-tom-aby-brali-bezpecnost-na-stadionech-vazne.aspx).

SIRC. (1996). Football violence in Europe. A Repot to the Amsterdam group, online text. (www.sirc.org/publik/football_violence.pdf).

Smolík, J. (2008). Fotbalové chuligánství. „Historie, teorie a politizace fenoménu“. Karlovy Vary: Zdeněk Plachý - vydavatelství \& nakladatelství.

Smolík, J. (2010). Subkultury mládeže: uvedení do problematiky. Praha: Grada.

Spaaij, R. (2006). Understading Football Hooliganism: A Comparison of Six Western European Football Clubs. Amsterdam: Amsterdam University Press.

Spaaij, R. \& Viñas, C. (2005). Passion, Politics and Violence: A Sociohistorical Analysis of Spanish Ultras, Soccer and Society, Vol. 6, No. 1, pp. 79-96.

SPF Intérieur. (2006). Étude du supportérisme et des manifestations de violence dans et autour des stades de football en Belgique, on-line text (https://besafe.ibz.be/NL/Academici/onderzoek_recherche/Documents/Rapport\%20final\%20Hool.pdf).

Suchan, O. (2010). „Rezolutní ministr vnitra Radek John: Vstupenky na jméno jsou klíčové“, Lidovky.cz, 11-11-2010 (http://sport.lidovky.cz/rezolutni-ministr-vnitra-radek-john-vstupenky-na-jmeno-jsou-klicove-1js-/fotbal.aspx?c= A101111_111114_In-fotbal-prvni-liga_ant).

Suchánek, M. \& Mareš, M. (2013). Sociální prevence a pedagogické aktivity proti diváckému násilí: přehled situace v Německu a v České republice, STUDIA SPORTIVA, No. 1, pp. 111-120 (www.fsps.muni.cz/studiasportiva/dokument/ StSp-1371.pdf).

swissinfo. (2008). Football hooliganism is still alive and kicking, on-line text (http://www.swissinfo.ch/eng/football-hooliganism-is-still-alive-and-kicking/986192).

Tribunal Fédéral. (2014). Communiqué aux médias du Tribunal fédéral. Arrêts du Tribunal fédéral concernant le concordat sur les hooligans, on-line text (http://www.bger.ch/fr/press-news-1c_176_2013-t.pdf).

Tsoukala, A. (1996). Réponses policières en Grande-Bretagne et en Italie. Vers une homogénéisation des stratégies policières en Europe?, Les Cahiers de la sécurité intérieure, Vol. 26, 4e trimestre, pp. 108-117 (http://www.cahiersdelasecuriteetdelajustice.fr/sites/default/files/fichiers/ancienne_serie/CSi26.pdf).

Tsoukala, A. (2013). Controlling football-related violence in France: law and order versus the rule of law, Sport in Society, Vol. 16, No. 2, pp. 140-150.

Všechny elektronické zdroje jsou ověřeny k 14. červnu 2015. 